\title{
Branching features of apple cultivars in integrated and organic production systems
}

\author{
Dremák, P., Csihon, Á. \& Gonda, I. \\ University of Debrecen, Faculty of the Agricultural and Food Sciences and Environmental Management, Institute of Horticulture \\ 138. Böszörményi str., Debrecen, H-4032, Hungary \\ Author for correspondence: Csihon, Á. (csihonadam@agr.unideb.hu)
}

\begin{abstract}
Summary: In our study, vegetative characteristics of 39 apple cultivars were evaluated in environmentally friendly production systems. Numbers of the branches of the central leader in different high zones were shown. According to our results, number of the branches of the axis was probably larger in the integrated production system, compared to the organic one, which is related to the conditional status of the trees. Based on our experiences training and maintaining canopies in integrated system was easier, as relative more extensive canopies were needed in organic farming.
\end{abstract}

Dremák, P., Csihon, Á., Gonda, I. (2018): Branching features of apple cultivars in integrated and organic production systems. International Journal of Horticultural Science 24 (3-4): 11-14. https://doi.org/10.31421/IJHS/24/3-4./2045

Key words: organic farming system, integrated farming system, growing characteristics, number of branches

\section{Introduction}

Knowledge of the vegetative characteristics of fruit trees is an essential tool for developing efficient production technology. Growing balance means the near optimal ratio between the longer shoots serving for the growth of the tree size and cropping surface respectively the short shoots serving for the fruit bearing. This state is necessary both for the time of turning to bearing of the young trees and both for the nearly permanent annual yields of the bearing trees (Bubán, 1998, 2003).

The most important regulatory factors of the fruit trees size (genetically determined) according to Faust (1989) are the arrangement of branches (e.g. acrotonic or basitonic branching pattern), the branching angle, the length of the internodes of the shoots, and - regardless of the previous three - the vigor. Based on Lespinasse's (1980) classification apple cultivars can be described with basitonic (e.g. cv 'Starkrimson'), acrotonic (e. g. cvs 'Rome Beauty', 'Gloster') or mesotonic (e.g. cv 'Red Delicious') branching pattern.

Vigor is mainly regulated by hormones, namely the relations of the auxins, cytokines and gibberellins. This is principally determined by inherited properties of the rootstock and the cultivar. However hormonal activity is also influenced by ecological factors and production technology specialties (Webster, 2005).

Production value of the cultivars is determined by the growing and the fruit bearing characteristics and the fruit quality in a complex way. Among the features of the cultivars growing characteristics are not detailed in most of the cultivar descriptions, they are handled just superficially. However comparing the vegetative parameters of the trees and canopies can ensure useful information for the producers during the tree training and maintaining (Csihon, 2015; Csihon et al. 2015).

In previous studies (Holb et al., 2012, 2017; Holb, 2000, 2007, 2008; Holb and Scherm, 2008; Dremák et al., 2015,
2016, 2017), the effect of integrated and organic production on the trunk, central axis, branch thickness and fungal diseases was examined. The aim of our study was to show the number of the branches of the central leader in various height of the tree in integrated and organic production.

\section{Materials and methods}

In our examinations vegetative characteristics of 13 worldwide known ('Gala Must', 'Golden Reinders', 'Csányi Jonathan', 'Ozark Gold', 'Elstar', 'Mutsu, Jonagold', 'Golden, Orange', 'Ruby Gala', 'Idared', 'Granny Smith', 'Pinova', 'Topaz'), 13 resistant ('Pilot', 'Reka', 'Relinda', 'Renora', 'Reglindis', 'Releika', 'Rewena', 'Retina', 'Remo', 'Liberty', 'Reanda', 'Resi', 'Faw 7262') and 13 historical ('Batul', 'Mosolygós batul', 'Nyári fontos', 'Téli aranyparmen', 'Téli banán', 'Téli piros pogácsa', 'Darusóvári', 'Fertődi téli', 'Francia renet', 'London pepin', 'Gravensteini', 'Téli fehér kálvil', 'Húsvéti rozmaring') apple cultivars were evaluated.

Location of the experiments was at Pallag Experimental Station, University of Debrecen. Orchard was planted in 1997 with 4 × 1.5 m distances. Rootstock of the scion was M.26, and the trees were trained to free spindle canopy.

Among the growing features number of the branches of the central leader in different high zones is shown in two environmentally friendly production systems. This parameter is related with the ramification ability of the cultivars, which is determined by not only the genetic properties, but the elements of the production technology affecting the plant condition.

Observations were performed in 5-5 trees per each cultivar and each production system. Number of the branches was counted in the different height zones of the tree (lower, middle, upper third) and the data were calculated to 1 meter leader length, which helps the objective evaluation. 


\section{Results and discussion}

Number of the branches emerging from the central leader

In Figure 1 number of the branches emerging from the central leader referring to the total tree can be seen. Data shows that the number of the branches is higher in the integrated production system, except for cvs 'Elstar','Gravensteini' and 'Téli fehér kálvil'.

Among the cultivars 'Téli piros pogácsa' $(12.4 ; 11.3)$, and 'London pepin' $(12.0 ; 10.5)$ can be described with higher number of branches. $\mathrm{Cv}$ 'Téli fehér kálvil' developed minimally more branches $(11.7 ; 11.9)$ in the organic farming system, similarly to the cvs 'Gravensteini' $(8.4 ; 8.6)$ and 'Elstar' $(8.8 ; 9.8)$. It can be seen obviously that the circumstances of the integrated production technology are more favorable to the ramification of the cultivars, which also reflects its better plant condition status.

\section{Number of the branches in the lower third of the canopy}

Number of the branches in the lower region of the trees influences significantly the possibility of the canopy training and maintaining (Figure 2).

In integrated growing system cvs 'Gravensteini' (1.9), 'Remo' (2.3), 'Fertődi téli' (2.3) 'Téli banán' (2.3) and 'Reanda' (2.4) presented unfavorable small number of branches in the lower region of the tree. These low values are quite interesting, as cultivars were trained to free spindle canopy, where 4-5 main scaffold branches were created in the non-bearing period.

Cvs 'Mutsu' (5.0) and 'London pepin' (6.0) displayed the highest number of branches besides that, they presented the lowest branch thickness values, based on our previous work (Dremák et al, 2017). Comparing the two production systems among the cultivars 'Jonica' (3.8; 3.1) and 'London pepin' $(6.0 ; 4.9)$ showed the largest difference, latter one also reaching the highest ramification.

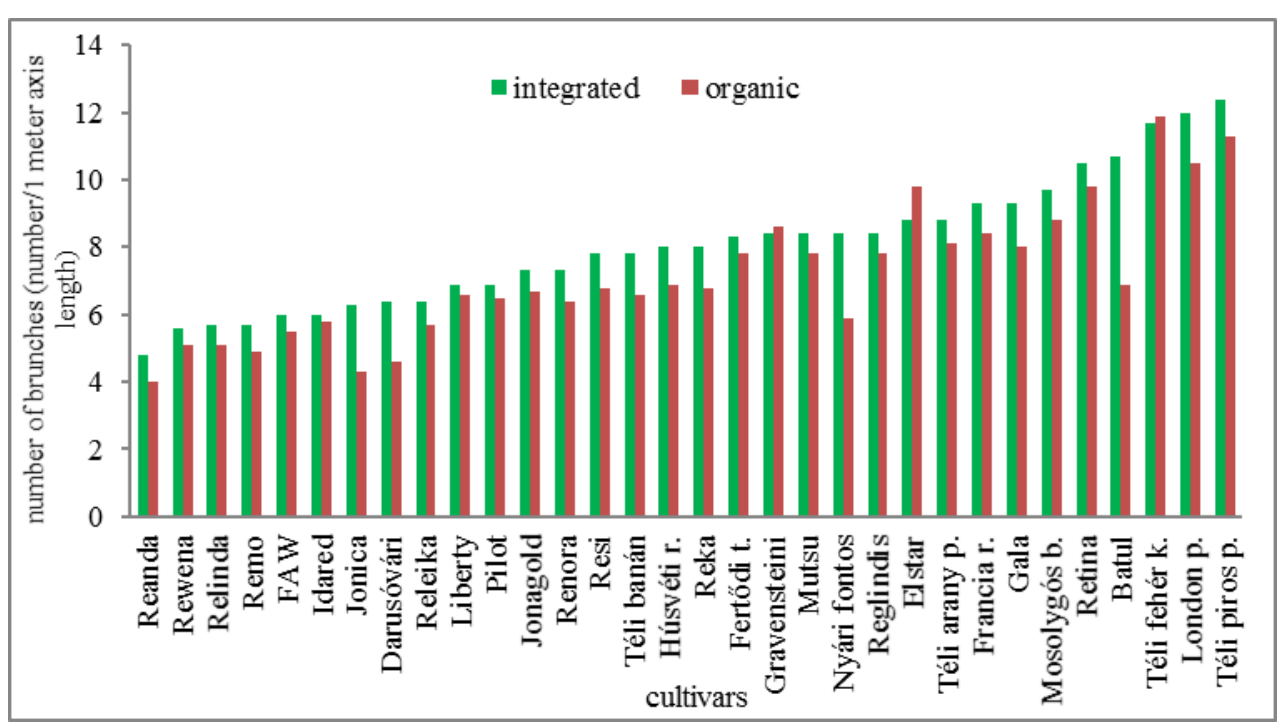

Figure 1. Number of branches per 1 meter axis length in environmentally friendly production systems (Debrecen-Pallag, 2010)

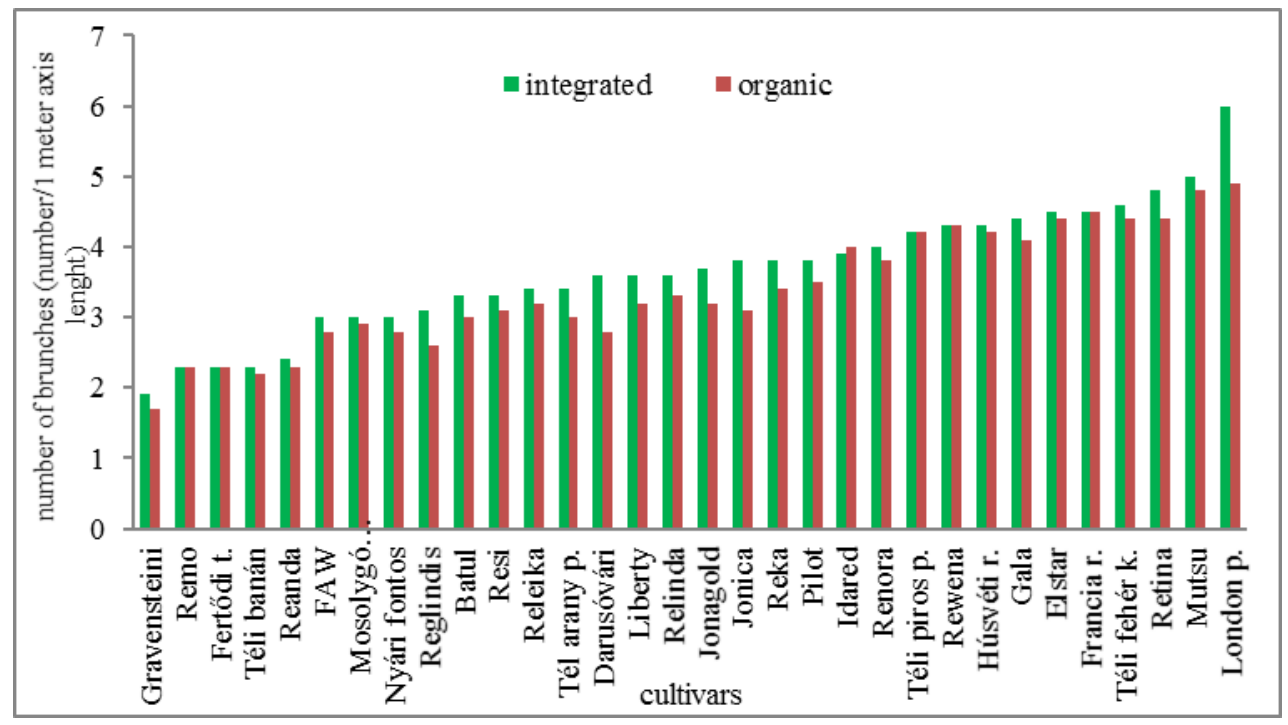

Figure 2. Number of branches of the central axis in the lower third of the canopy (Debrecen-Pallag, 2010)

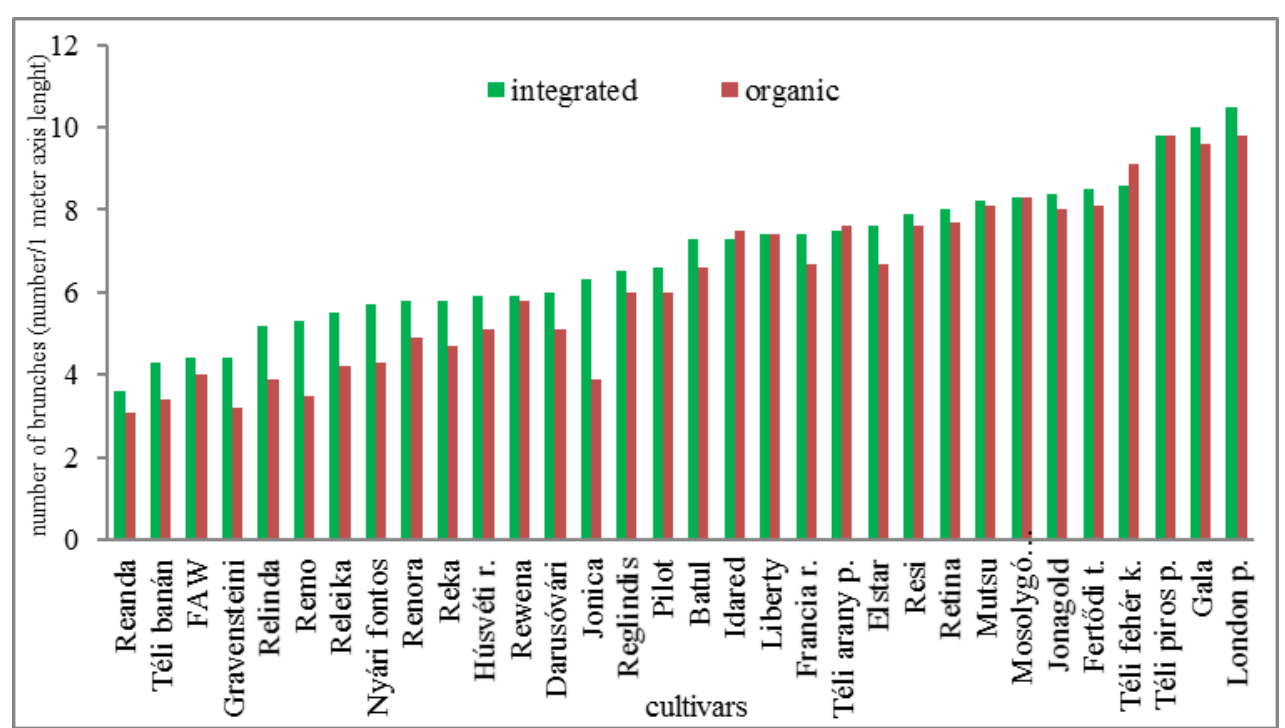

Figure 3. Number of branches of the central axis in the middle third of the canopy (Debrecen-Pallag, 2010) 


\section{Number of the branches in the middle third of the canopy}

During creating and maintaining the canopy we should intend to have branches of which thickness and length are decreasing from the bottom to the up. Regarding the producing surface middle part of the tree has a huge role (Figure 3), as even $30 \%$ of the high quality yield can bear here.

In integrated farming system based on the data of the branch number of the middle region of the trees difference between the extreme values is almost threefold, as the diverse ramification ability of the cultivars is well visible.

Lowest values can be seen with cv 'Reanda' (3.6), as in the case of cvs 'Téli banán' (4.3), 'FAW' (4.4) and 'Gravensteini' (4.4) less than 5 branches were counted/1 meter axis length. Highest ramification was observed with cvs 'London pepin' (10.5), 'Gala' (10.0) and 'Téli piros pogácsa' (9.8). Taking into account also their branch thickness (Dremák et al., 2017), that fact is not surprising, as they can be grouped to the cultivars with thin branches.

In the organic production system lowest values were measured with cvs 'Reanda' (3.1), 'Gravensteini' (3.2) and 'Remo' (3.5), as their branch thickness were quite high. It is worth mentioning yet that cv 'Jonica' displayed low number of branches (3.9), besides its thickness were outstandingly large.

\section{Number of the branches in the upper third of the canopy}

Ramification ability of the higher third of the canopy can be influenced by not only the characteristics of the cultivar, but also by the annual thinning pruning and the yield of the currant years. In this region, which is the most unfavorable part of the canopy regarding the vigor, huge differences are noted among the cultivars. It can be seen that the difference between the fewest and most branched varieties can reach up to four to six times (Figure 4).

The most moderately branching varieties are 'Rewena' (5.6) and 'Idared' (6.6). Contrary to this cvs 'Elstar' (18.4), 'Gravensteini' (21.1) and 'Téli fehér kálvil' (22.3) are tend to became extreme dense in the upper third of the tree compared to the other cultivars. It is seen also, that these three cultivars presented higher branch number in the organic farming system, than in the integrated one.

\section{Conclusions}

In the organic production technology, fewer number of branches was counted on the central leader in all high zones, compared to the integrated production technology. In the integrated system thickness of the branches were obviously thinner (Dremák et al., 2017), which can be related with their higher number. Branches spaced with larger distances from each other in the organic growing system can develop more freely, thus the concurrency is more moderate among them, on the other hand the better illumination helps also their thickening. Of course, the reason of the higher branch thickness can be also the lower yields of the organic production, which influences the vegetative processes, as we have seen in the case of the trunk thickness values (Dremák et al., 2015).

According to our examinations, number of the branches of the central leader is demonstrably larger in the integrated production system, compared to the organic one. Based on Gonda's (1979) opinion it can be related with the condition status of the trees. When trees are in adequate condition status the more moderate apical dominance can promote more bud growth, namely higher ramification, than the worse condition status of the trees, which is accompanied with stronger apical dominance. This also means that it is indirectly provable that organic growing system can cause weaker plant condition.

Based on our previous and current results it can be stated, that each element of the canopy structure (trunk, central leader and branch thickness and number of branches) confirms that the possibilities of the optimal canopy training and maintaining are more favorable in integrated production system than in organic one. Its clear practical significance can also be formulated. Method of the canopy training and maintaining are diverse in the two different technologies depending on the growing and ramification characteristics. Maintaining the richer branching trees are easier, requires relative less pruning interventions, compared to the weaker ones. In the case of the latter ones the 'rampant' vegetative and thickening features of the branches can cause sectorial imbalance conditions.

Therefore training and maintaining canopies in integrated systems needs less effort, as relative more extensive canopies are needed in organic farming. This coincides with the finding of Gonda (2005) that it is advisable to plant trees with larger spacing in organic farming for the later maintaining.

In the organic system the cropping surface of the tree (the height and the possibility of the heightening is limited) is restricted thanks to the strongly tapering central axis (Dremák et al., 2016), therefore these trees require larger plant-to-plant distance and more extensive canopy because of their stronger bottom lateral growth.

Our results shows, that the majority of the cultivars develop $4-20 \%$ more branches in the integrated production system. Accordingly maintaining the optimal canopy is easier thanks to the wider choice during the pruning, as risk of the balding processes are less.

Figure 4. Number of branches of the central axis in the upper third of the canopy (Debrecen-Pallag, 2010) 


\section{References}

Bubán, T. (1998): A gyümölcstermő növények növekedési tulajdonságai. In: Gyümölcsfajta-ismeret és -használat. Szerk.: Soltész, M. Mezőgazda Kiadó. Budapest. 75-97. p.

Bubán, T. (2003): A növekedési tulajdonságok általános jellemzése. In: Gyümölcstermesztési alapismeretek. Szerk.: PAPP, J. Mezőgazda Kiadó. Budapest. 128-131. p.

Gonda. I. (1979): A metszés időzítése, mértéke és a fák kondíciójának kölcsönhatásai. Újabb kutatási eredmények a gyümölcstermesztésben 6:21-28.

Gonda I. (2005): Az ökológiai növényvédelem közvetett elemei. In. Holb, I. (szerk.) A gyümölcsösök és a szőlő ökológiai növényvédelme. Mezőgazda Kiadó, Budapest. 34-40. p.

Csihon, Á. (2015): Új almafajták növekedési, terméshozási és gyümölcsminőségi tulajdonságainak vizsgálata. Doktori értekezés. DE MÉK. 173. pp.

Csihon, Á., Holb, I., Gonda, I. (2015): Growing characteristics of apple cultivars and canopies. International Journal of Horticultural Science 21(1-2): 7-10. p. https://doi.org/10.31421/IJHS/21/1-2./1150

Dremák, P., Csihon, Á., Gonda, I. (2015): Growing characteristics of apple cultivars in environmentally friendly growing systems. International Journal of Horticultural Science 21(3-4): 7-10. p. https://doi.org/10.31421/IJHS/21/3-4./1159

Dremák, P., Csihon, Á., Gonda, I. (2016): Vegetative parameters of apple cultivars in integrated and organic production systems. International Journal of Horticultural Science 22(1-2): 15-18. p. https://doi.org/10.31421/IJHS/22/1 2./1177

Dremák, P., Csihon, Á., Gonda, I. (2017): Effect of the environmentally friendly production systems on the vegetative characteristics of apple cultivars. International Journal of Horticultural Science 23(1-4): 11-14 p. https://doi.org/10.31421/IJHS/23/1-4./1194
Faust, M. (1989): Physiology of temperate zone fruit trees. John Willey and Sons. New York - Singapore. 337. p.

Holb, I. J. (2000): Disease progress of apple scab caused by Venturia inaequalis in environmentally friendly growing systems. International Journal of Horticultural Science 6(4): 56-62. https://doi.org/10.31421/IJHS/6/4/225

Holb, I. J. (2007): Classification of apple cultivar reactions to scab in integrated and organic apple production systems. Canadian Journal of Plant Pathology 29(3): 251-260. https://doi.org/10.1080/07060660709507467

Holb, I. J. (2008): Timing of first and final sprays against apple scab combined with leaf removal and pruning in organic apple production. Crop Protection 27(3-5): 814-822. https://doi.org/10.1016/j.cropro.2007.11.009

Holb, I. J. (2017): Categorization of apple cultivars based on seasonal powdery mildew disease progression in two disease management systems over 12 years. Trees-Structure and Function 31(6): 1905-1917. https://doi.org/10.1007/s00468017-1595-6

Holb, I. J., Dremák, P., Bitskey, K., Gonda, I. (2012): Yield response, pest damage and fruit quality parameters of scabresistant and scab-susceptible apple cultivars in integrated and organic production systems. Scientia Horticulturae 145: 109 117. DOI: $10.1016 /$ j.scienta.2012.08.003

Holb, I. J., Scherm, H. (2008): Quantitative relationships between different injury factors and development of brown rot caused by Monilinia fructigena in integrated and organic apple orchards. Phytopathology 98(1): 79-86. Doi: 10.1094/PHYTO98-1-0079.

Lespinasse, J M. (1980): Perspectives de l'horticulture. No. 15:27-102. Ministere de l' Agr. Quebec, Canada.

Webster, A. D. (2005): Shoot growth. In: Tromp, J. Webster, A. D. - Wertheim, S. J.: Fundamentals of temperate zone tree fruit production. Backhuys Publishers. Leiden. 120135. 